\title{
Application Of Metaheuristic Methods For Education Scheduling (Case Study Of Bali State Politechnic)
}

\author{
Komang Ayu Triana Indah ${ }^{1}$, Ida Bagus Putra Manuaba ${ }^{2}$ \\ Electrical Engineering Departement \\ Politeknik Negeri Bali \\ Bali, Indonesia \\ 1'triana_indah@pnb.ac.id, ${ }^{2}$ manuaba.putra@gmail.com
}

\begin{abstract}
Lecture Scheduling Problems are very complex problems, where the core of the scheduling is how to schedule several components consisting of students, lecturers, space, time, and courses by taking into account certain limitations and constraints. The aim to be achieved is to apply the Tabu Search Metaheuristic method which is applied in the Lecture Scheduling system. Every step taken by Tabu Search is taken based on the results of the cost calculation carried out in each iteration to select a neighbor solution which will be the next current best solution. In this study an application was designed to apply Tabu Search Metaheuristic method through lecturing scheduling applications by using Microsoft Visual Basic programming language by entering several parameters namely Data Lecturer, Course, Room, and several variables from each parameter which were then processed to produce scheduling lecture. The results obtained from the use of Tabu Search Metaheuristic method are scheduling odd semester and even semester lectures in the Informatics Management Study Program, Electrical Engineering Department, Bali State Polytechnic.
\end{abstract}

Keywords: metaheuristic; tabu search; constraint; scheduling lectures

\section{INTRODUCTION}

Scheduling problems in general are assignment activities related to a number of constraints, a number of events that can occur in a certain period of time and place / location so that the objective function is as close as possible. Submission of information to academic institutions is very important, especially information related to lecture activities. One of them is information on class schedules. Lecture scheduling problems or the University Course Timetabling Problem (UCTP) are very complex problems that are often faced by every university. The essence of scheduling lectures is how to schedule a number of components consisting of class, space, and time with a number of restrictions and certain constraints. Lecture scheduling is not an easy job, where the core of this problem is how to schedule various components consisting of students, lecturers, space and time by taking into account certain limitations and conditions. In research conducted in the Information Management Study Program, Electrical Engineering Department, Bali State Polytechnic.

\section{A. Research Method}

The object under study is the lecture scheduling system in the Informatics Management Study Program, Electrical Engineering Department, Bali State Polytechnic by applying Tabu Search metaheuristic method. This Information Scheduling System can also apply to all departments in the Bali State Polytechnic according to user needs. This lecture scheduling system is expected to be able to help the academic section to make scheduling of courses per semester in accordance with the level of importance of each department more optimally. This research is carried out following the information retrieval process to ensure interconnection between interacting processes, as shown in Figure 1.

\section{SCHEDULING LECTURES}

Submission of information to academic institutions is very important, especially information related to lecture activities. One of them is information on class schedules. Lecture scheduling is not an easy job, where the core of this problem is how to schedule various components consisting of students, lecturers, space and time by taking into account certain limitations and conditions. From the problems of existing lecture scheduling optimization, a mathematical model will be built in which this mathematical model is a graph form whose inter-node connectivity is a representation of constraints that the system should not violate. The constraints that are hard constraints are as follows:

- Class is only scheduled once for each subject [hard contstraint I].

- The same class cannot study in different spaces at one time [hard contstraint II].

- The same class cannot study more than one subject at a time [hard contstraint III].

- The course will be given a continuous time allocation according to the credits owned by the subject (no credit from the course is cut by another schedule or there is a change of day) [hard contstraint IV].

- If the time given is not sufficient for scheduling, the system will not produce a schedule [hard contstraint V]. 

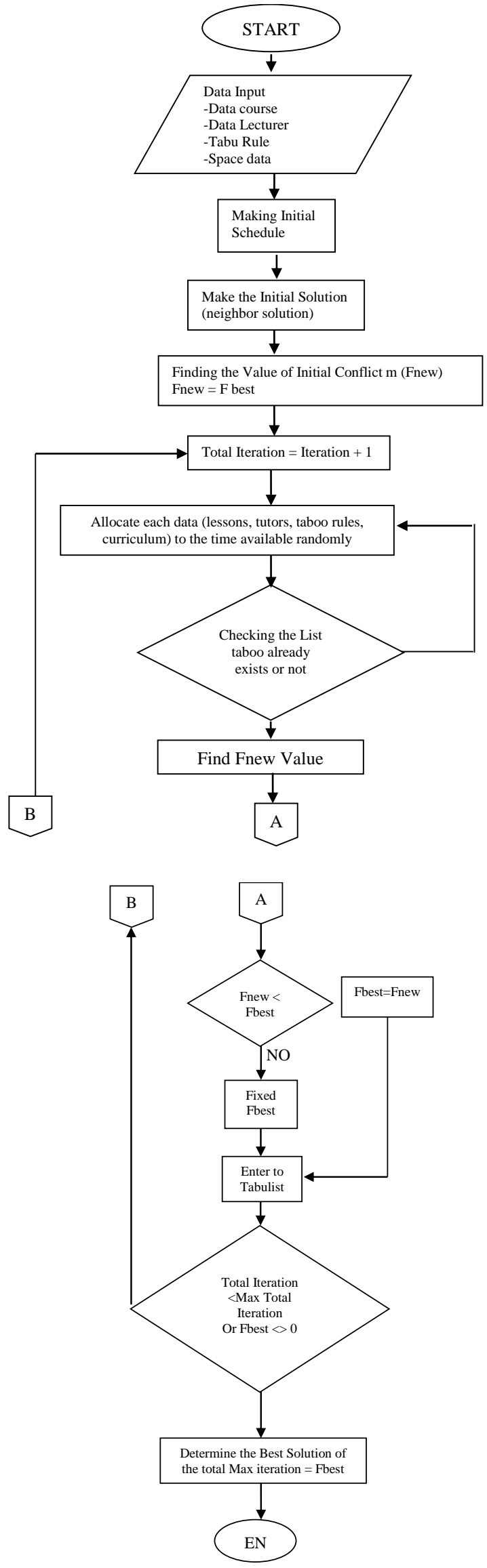

Fig. 1. Flowchart Lecture Scheduling System with Tabu Search Metaheuristic Method
Good scheduling is scheduling that does not contain clashes between scheduled components, in this case in the form of class, time, and space. In addition to hard constraint, the scheduling of lectures also defined some soft constraints so that the results obtained were better solutions. The things that should be fulfilled as soft constraints are as follows:

- The space used by a class in one day is expected to be in the same building [soft contraint I].

- From the five days of lectures in one week, it is expected that each class should get one or two days of empty lectures [II soft contradiction].

- In one day of study, it is expected that the number of lecture hours for one class is not too much and not too little, preferably between four to six hours of lectures [III soft contradiction].

This soft contraint is not necessarily fulfilled, but it is expected to be fulfilled so that the solution obtained is a better solution. Based on the hard constraint above, a graph will be built which is a mapping of the event (the event is a representative of class, level, semester and course code) which will be scheduled against time and placed in space, which will be solved using Tabu Search algorithm so resulting in scheduling lectures with good solutions.

\section{A. Application Design Will Be Developed}

The implementation of Tabu Search metaheuristic method for scheduling courses follows the following stages.

\section{B. Constraint Classification}

The regulations that are owned by a university in making the class schedule can be summarized and grouped into 2 groups according to the level of obligation the regulation is fulfilled. These two groups are described in the Hard Constraint and Soft Constraint sections.

1) Hard Constraint: Hard Constraint is defined as a mandatory constraint that must be met in the algorithm calculation process. The following is a list of Hard constraints in college scheduling problems and their explanations:

- The lecturer schedule cannot clash.

- The room used must not clash. Lecturers must teach courses that are in accordance with the provisions of the Chairperson of the Department

- Lecturers may not get a teaching schedule exceeding their credit quota.

- All classes opened must get lecture time and space.

- The number of students in one class must not exceed the capacity of the room.

- Class courses that require a special room must be scheduled in the right room.

- Course classes that are more than 1 meeting per week must receive sequential schedules.

2) Soft Constraint: Different from hard constraints, the constraints included in the soft constraint category are obstacles that cannot always be fulfilled in the process of forming class schedules. The following is a soft constraint list of lecture scheduling problems, along with an explanation: 
- For each class that is opened, there will be lecturers teaching.

- A lecturer cannot get a teaching schedule of more than 3 meetings a day.

- Schedule of teaching lecturers in a day is arranged in sequence without pause.

- Student class schedules in a day are arranged in sequence without a break.

- The number of students allocated to one classroom is as close as possible to the capacity of the room

- The same subject classes are arranged for different days and hours.

- Lecturers must get a teaching schedule in accordance with the time of their willingness to teach.

\section{CORE ALGORITHMS}

The basic principle of the Tabu Search algorithm is to process an empty initial solution until it becomes a final solution. This algorithm uses class and subject relations as variables and uses lecturers, subjects, time, and room as values that will be entered into variables

Every step taken by Tabu Search is taken based on the results of the cost calculation carried out in each iteration to select a neighbor solution which will be the next current best solution. Termination of the process occurs if the number of scheduled classes has met the requirements or interaction of the user requires the termination of the process.

\section{Cost CALCULATION}

Cost calculations in Tabu Search are detecting constraint violations in each class. Detection of these violations was carried out to determine which class should be corrected, then selecting lecturers and lecture hours that must be selected to improve the class schedule. The calculation of the cost in the Tabu Search algorithm has been designed to produce a value of 0 , if the class has the best composition of lecturers and lecture time, which does not violate all existing constraints. The formula for calculating the cost value of a class is as follows (Riwansyah, 2005):

The change in cost will be a long chain reaction if the class that gets resource allocation is a Multimatakuliah class with a sufficient number of sub subjects. The higher the cost, it can be concluded that the schedule owned by the class contains many soft constraints. For the desired solution to be achieved, each constraint violation is defined as the value of the different costs.

\section{DATA INPUT}

For the data input process, it consists of:

- Data entry process in the form of lecturer data, course data, space data, and lecture data. Lecturer data is filled by the lecturers themselves by filling in the teaching data form, while the room is determined by the Program Secretariat, scheduling lectures and examinations to be stored in the database.

- The process of entering the subject data is offered each semester, including the determination of the number of classes offered by the lecture that are adjusted to the ability of the teaching lecturer.

\section{OUTPUT DATA}

The output data produced is:

- Report (print out) the class schedule, which contains data on the course of the course held each semester. This report is then used by students for college key-ins.

- Report (print out) the lecturer schedule, is a lecturer teaching report submitted to the lecturer concerned to find out the teaching schedule.

\section{RESUlT AND DisCUSSION}

\section{A. Main Menu}

This Main Menu is the initial form displayed when the software is run. In the main menu there are menus that have functions related to data entry, and data processing as shown in Figure 2 below

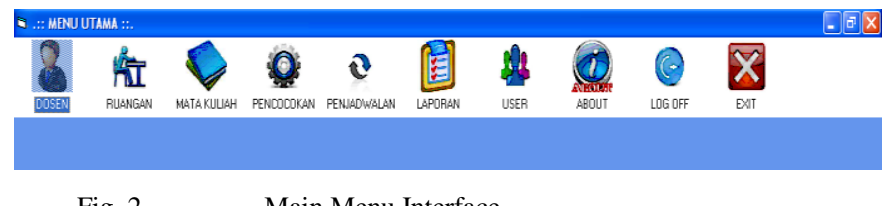

Fig. 2.

Main Menu Interface

Information:

- Home Menu: This menu is used to display the system menu view.

- Data Input Menu

B. Lecturer Data Input

This menu is used for inputting data of lecturers who teach, whether permanent lecturers or non-permanent lecturers.

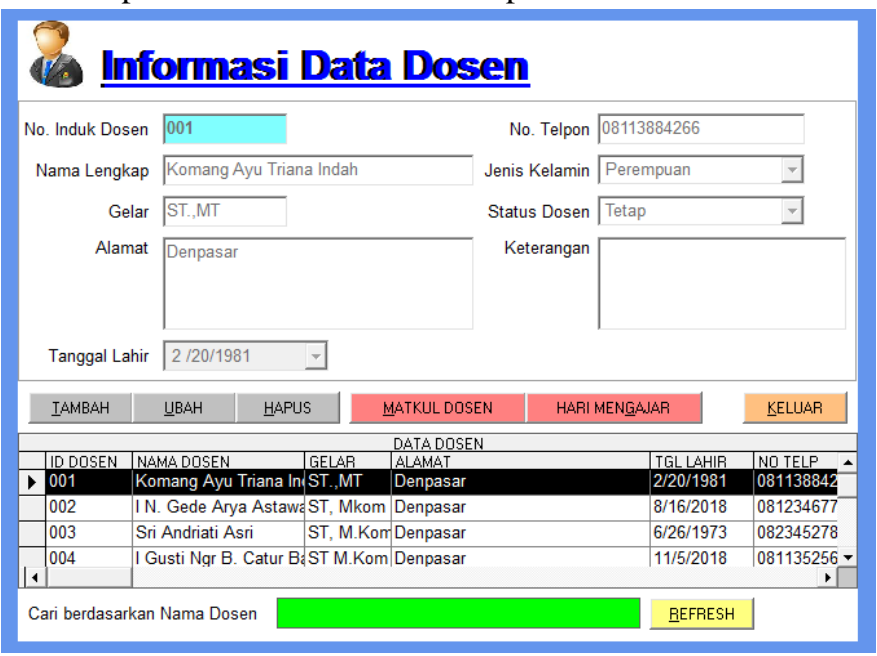

Fig. 3. Lecturer Menu

\section{Input Data Room}

This menu is used for entering the room data used. 


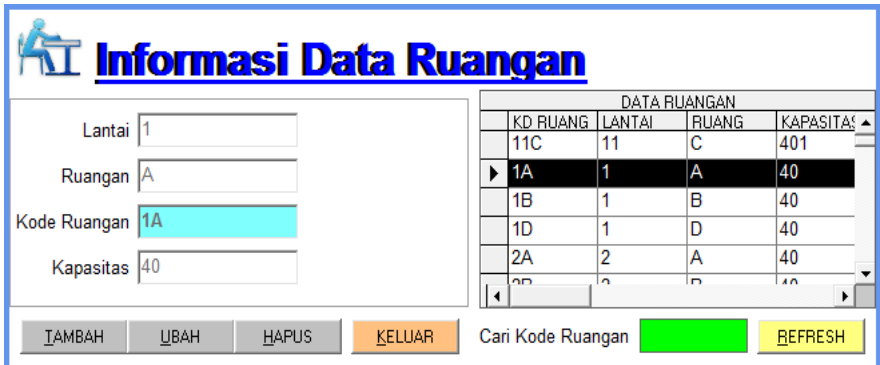

Fig. 4. Classroom Menu

\section{Input Subject Data}

This menu is used to enter the course data, either odd semester or even semester.

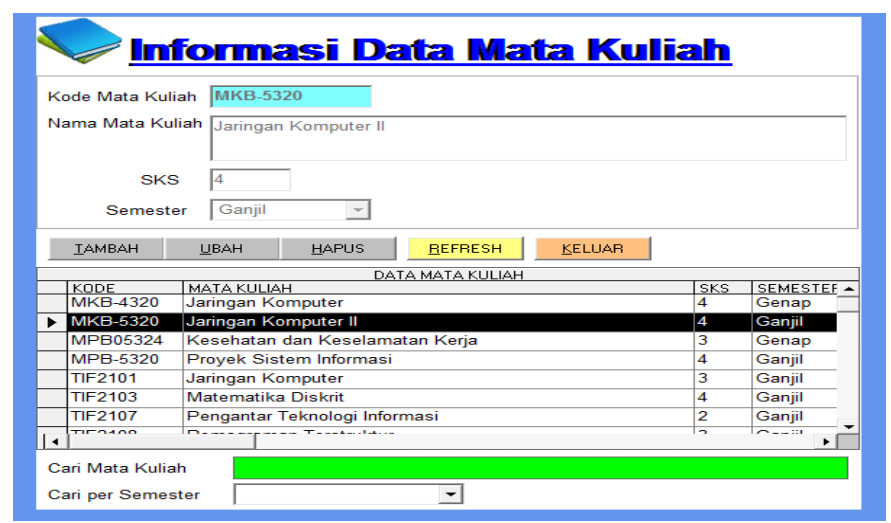

Fig. 5. Subject Menu

\section{E. Input Match / Match data}

This menu is used to match input data with lecturer teaching request data.

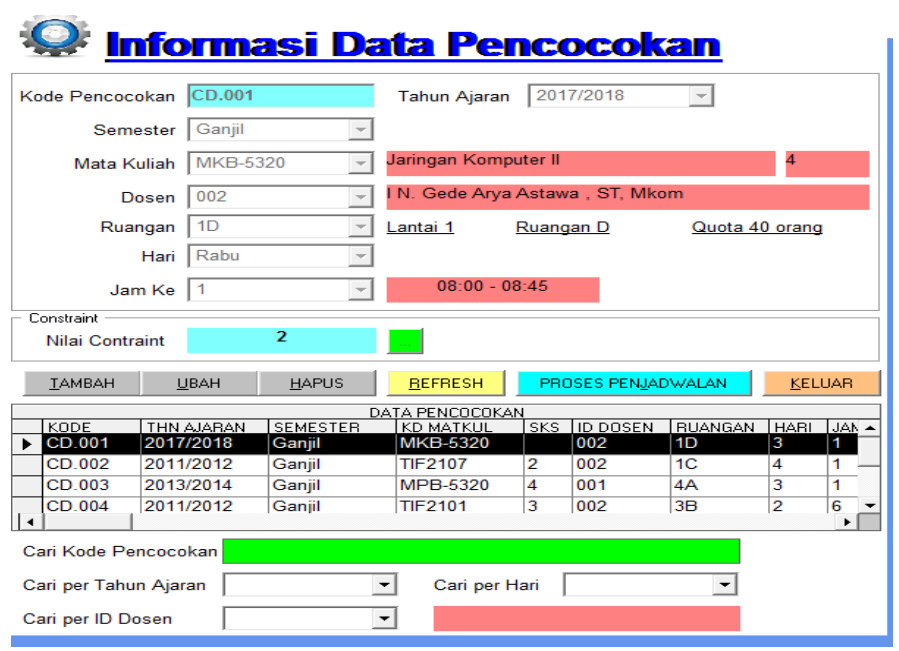

Fig. 6. Match Menu

\section{F. Scheduling Process Menu with Tabu Search}

This menu is used to process scheduling lectures.

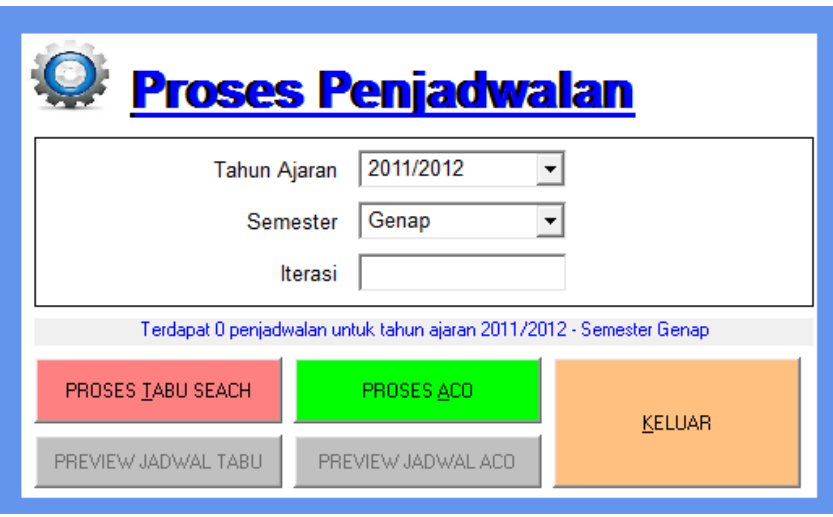

Fig. 7. Schedulling Menu

\section{G. Menu Exit}

This menu is used to exit the system

\section{H. Output Database}

The following is the output display from the menu contained in the scheduling program application. Scheduling output can be seen in figures 8.9 and 10

\section{Lecturer Data Output}

\section{Laporan Data Dosen}

\begin{tabular}{|c|c|c|c|c|c|c|c|c|}
\hline No & Dosen & Nama Dosen & Gelar & Alamat & Tgl. Lahir & No. Telp & Jenkel & Status \\
\hline 1 & 001 & Komang Ayu Triana Indah & ST.MT & Denpasar & 20 Feb 1981 & 08113884266 & Perempuan & Tetap \\
\hline 2 & 002 & I N. Gede Arya Astawa & ST, Mkom & Denpasar & 16 Aug 2016 & 081234677666 & Laki-Laki & Tetap \\
\hline 3 & 003 & Sri Andriati Asri & & Denpasar & 26 Jun 1973 & 082345278968 & Perempuan & Tetap \\
\hline 4 & 004 & I Gusti Ngr B. Catur Bawa & STM.K & Denpasar & 05 Nov 2018 & 081135256587 & Lakk-Laki & Tetap \\
\hline 5 & 005 & Ni Wayan Wisswani & ST.MT & Badung & 03 Jun 1980 & 257 & Perempuan & Tetap \\
\hline 6 & 006 & I Wayan Suasnawa & ST.MT & Denpasar & 11 oct 1975 & 08123453244 & Laki-Laki & Tetap \\
\hline 7 & 007 & Putu Gede Sukarata & ST.MT & Denpasar & 03 Aug 1972 & 081338546786 & Laki-Laki & Tetap \\
\hline 8 & 008 & Putu Manik Prih atini & ST.MT & Denpasar & 17 Mar 1930 & 08123457786 & Perempuan & Tetap \\
\hline 9 & 009 & I Wayan Budi Sentana & ST,M.M.Ko & Donpasar & 11 May 1981 & 08235667765 & Laki-Laki & Totap \\
\hline 10 & 013 & I Wayan Candra Winetra & ST,M.Mo $\mathrm{K}$ & Denpasar & 31 May 1980 & 085547858979 & Laki-Laki & Tetap \\
\hline 11 & 014 & Putu Indah Ciptayani & & Denpasar & 13 Apr 1985 & 081236549865 & Perempuan & Tetap \\
\hline
\end{tabular}

Fig. 8. Lecturer Data Output

\section{J. Classroom Data Output}

\section{I apolan Data IRUanoan}

\begin{tabular}{|c|c|c|c|c|}
\hline No & Kd. Ruangan & Lantai & Ruang & Kapasitas \\
\hline 1 & $1 \mathrm{~A}$ & 1 & A & 40 \\
\hline 2 & 18 & 1 & B & 40 \\
\hline 3 & 10 & 1 & $c$ & 40 \\
\hline 4 & 10 & 1 & $\mathrm{D}$ & 40 \\
\hline 5 & $2 A$ & 2 & A & 40 \\
\hline 6 & $2 \mathrm{~B}$ & 2 & $B$ & 40 \\
\hline 7 & $2 \mathrm{c}$ & 2 & $c$ & 40 \\
\hline a & $2 \mathrm{D}$ & 2 & $\mathrm{D}$ & 40 \\
\hline 9 & 3A. & 3 & A & 40 \\
\hline 10 & $3 \mathrm{~B}$ & 3 & $\mathrm{~B}$ & 40 \\
\hline 11 & 30 & 3 & c & 40 \\
\hline 12 & 30 & 3 & $\mathrm{D}$ & 40 \\
\hline 13 & $4 A$ & 4 & A & 40 \\
\hline 14 & $4 \mathrm{~B}$ & 4 & $\mathrm{~B}$ & 40 \\
\hline 15 & $4 \mathrm{C}$ & 4 & $\mathrm{c}$ & 40 \\
\hline 16 & $4 \mathrm{D}$ & 4 & $\mathrm{D}$ & 40 \\
\hline
\end{tabular}

Fig. 9. Classroom Data Output 


\section{H. Output Course Data}

\section{I aporan Data Mata Kuliah}

\begin{tabular}{|c|c|c|c|c|}
\hline \multirow{2}{*}{\multicolumn{2}{|c|}{\begin{tabular}{|c|c|} 
No & Kd. Matakuliah \\
\end{tabular}}} & Nama Matakuliah & SKs | & Semester \\
\hline & & Jaringan Komputer & & Genap \\
\hline 2 & МКВ-5320 & Jaringan Komputer II & ${ }_{4}$ & Ganjil \\
\hline 3 & MPB05324 & Kesehatan dan Keselamatan Kerja & 3 & Genap \\
\hline 4 & MPQ-5320 & Proyek Sistem Informasi & 4 & Ganjil \\
\hline 5 & TIF2 101 & Jaringan Komputer & 3 & Ganjil \\
\hline 6 & TIF2 103 & Matematika Diskrit & 4 & Ganjii \\
\hline 7 & TIF2 107 & Pengantar Teknologi Informasi & 2 & Ganjil \\
\hline 8 & TIF2 108 & Pemograman Terstruktur & 3 & Ganjii \\
\hline 9 & TIF2202 & Manajemen Proyek Sistem Informasi & 3 & Genap \\
\hline 10 & TIF 2204 & Pemrograman Visual & 4 & Genap \\
\hline 11 & TIF2209 & Algoritma \& Pemograman & 2 & Genap \\
\hline 12 & TIF3101 & Sistem Digital & 3 & GanjiI \\
\hline & TIF3218 & Praktikum Alpro & 1 & Genap \\
\hline 14 & UIN1206 & Bahasa Inggris & 2 & Genap \\
\hline
\end{tabular}

Fig. 10. Output Course Data

From the course data for the period 2017/2018 then inputted to the matching process (taboo list). In table 1 shows some local solutions are in a taboo list which in turn will be the next current best solution in the form of tabu search scheduling.

TABLE I. MATChING TABLE (TABU LIST)

\begin{tabular}{|c|l|l|l|l|l|l|l|l|l|}
\hline \multicolumn{9}{|c|}{ pencocokan } \\
\hline $\begin{array}{c}\text { kd_coc } \\
\text { ok }\end{array}$ & $\begin{array}{c}\text { thn_ajar } \\
\text { an }\end{array}$ & $\begin{array}{c}\text { Semest } \\
\text { er }\end{array}$ & $\begin{array}{c}\text { kd_matakul } \\
\text { iah }\end{array}$ & $\begin{array}{c}\text { sk } \\
\text { s }\end{array}$ & $\begin{array}{c}\text { id_dos } \\
\text { en }\end{array}$ & $\begin{array}{c}\text { kd_ruang } \\
\text { an }\end{array}$ & $\begin{array}{c}\text { ha } \\
\text { ri }\end{array}$ & $\begin{array}{c}\text { jam_ke } \\
\text { ke }\end{array}$ & $\begin{array}{c}\text { con } \\
\text { st }\end{array}$ \\
\hline CD.001 & $\begin{array}{l}2017 / 20 \\
18\end{array}$ & Ganjil & MKB-5320 & & 002 & $1 D$ & 3 & 1 & 2 \\
\hline CD.002 & $\begin{array}{l}2017 / 20 \\
18\end{array}$ & Ganjil & TIF2108 & 3 & 004 & $2 A$ & 3 & 1 & 3 \\
\hline CD.004 & $\begin{array}{l}2017 / 20 \\
18\end{array}$ & Ganjil & TIF2107 & 2 & 007 & $1 C$ & 3 & 1 & 3 \\
\hline CD.005 & $\begin{array}{l}2017 / 20 \\
18\end{array}$ & Ganjil & TIF2103 & 4 & 005 & $2 C$ & 2 & 5 & 3 \\
\hline CD.006 & $\begin{array}{l}2017 / 20 \\
18\end{array}$ & Ganjil & TIF3101 & 3 & 003 & $2 A$ & 3 & 5 & 3 \\
\hline \hline
\end{tabular}

From Table 1, there are several matching codes which are made as Local Solution for Tabu Search and placed in Tabu List (Match code database). A value of 0 is Global Min, and is the best Cost value. From Local Solution above, Final Solution is obtained from the results of scheduling Tabu Search in table 2 above as follows:

TABLE II. TABU SEARCH SCHEDULING

\begin{tabular}{|l|l|l|l|l|l|l||l|l|}
\hline \multicolumn{2}{|l|}{ jadwal_tabu } \\
\hline thn_ajaran & hari & kd_matakuliah & id_dosen & semester & kd_ruangan & jam_ke & cons \\
\hline $2017 / 2018$ & 3 & MPB-5320 & 001 & Ganjil & 4A & 1 & 3 \\
\hline $2017 / 2018$ & 4 & TIF2107 & 002 & Ganjil & 1C & 1 & 3 \\
\hline $2017 / 2018$ & 1 & BARU0101 & 004 & Ganjil & 1 C & 2 & 2 \\
\hline $2017 / 2018$ & 1 & BARU0102 & 005 & Ganjil & 1B & 4 & 2 \\
\hline $2017 / 2018$ & 3 & BARU0103 & 006 & Ganjil & 2A & 3 & 0 \\
\hline
\end{tabular}

\section{Scheduling Using The Tabu SEARCh Algorithm}

Tabu search optimization analysis on lecturing scheduling is an iteration calculation based on the number of days and the number of courses is as follows:

Because the number of courses in one period (2011/2012) is approximately 140 courses, it is assumed to simplify the calculation:
Number of days $(\mathrm{X})=5$ and Course $(\mathrm{Y})=4$

$\mathrm{X} 1 \mathrm{X} 2 \mathrm{X} 3 \mathrm{X} 4 \mathrm{X} 5$

Y1 161616801201202520

Y2 24242520241515

Y3 120242415120180

Y4 102424161802415

Need to add Y5 with the cost for each day is 0

\section{$\mathrm{X} 1 \mathrm{X} 2 \mathrm{X} 3 \mathrm{X} 4 \mathrm{X} 5$}

Y1 161616801201202520

Y2 242425202415

Y3 120242415120180

Y4 102424161802415

Y5 000000

Initial assignments 1-2-3-4-5 with Iteration $=5$, then obtained: Initial Assignment $=$

$12345=1616+24+2415+180+0=>$ Total Cost $=4235$

Global Min $=4235$

1st Iteration:

Taboo List:

112345

Next Alternative Assignment:

\section{$\mathbf{1}^{\text {st }}$ Iteration}

Tabu List :

112345

Penugasan Alternatif berikutnya :

P-1. $12345=\Rightarrow 1616+24+2415+180+0=4235$

P-2. $12354==>1616+24+2415+2415+0=6470$

P-3. $12435==>1616+24+120+16+0=1776$

>> Best So Far $=1776$

P-4. $12453==>1616+24+120+2415+0=4175$

P-5. $12534=\Rightarrow 1616+24+180+16+0=1836$

P-6. $12543==>1616+24+180+180+0=2000$

P-7. $13245=\Rightarrow 1616+2520+24+180+0=4340$

P-8. $13254==>1616+2520+24+2415+0=6575$

P-9. $13425==>1616+2520+120+2424+0=6680$

P-10. $13452==>1616+2520+120+2415+0=6671$

$\mathrm{P}-11.13524==>1616+2520+180+2424+0=6740$

$\mathrm{P}-12.13542==>1616+2520+180+180+0=4496$

$\mathrm{P}-13.14235==>1616+2415+24+16+0=4071$

$\mathrm{P}-14.14253==>1616+2415+24+2415+0=6470$

$\mathrm{P}-15.14325=\Rightarrow 1616+2415+2415+2424+0=8870$

P-16. $14352=\Rightarrow 1616+2415+2415+2415+0=8861$

$\mathrm{P}-17.14523==>1616+2415+180+2424+0=6635$

$\mathrm{P}-18.14532=>1616+2415+180+16+0=4227$

P-19. $15234==1616+15+24+16+0=1671$

> Best So Far $=1671$

P-20. $15243==>1616+15+24+180+0=1835$

$\mathrm{P}-21.15324==>1616+15+2415+2424+0=6470$

$\mathrm{P}-22.15342==>1616+15+2415+180+0=4226$

P-23. $15423==1616+15+120+2424+0=4175$

$\mathrm{P}-24.15432==>1616+15+120+16+0=1767$

P-25. $21345==1680+24+2415+180+0=4299$

P-26. $21354==>1680+24+2415+2415+0=6534$

$\mathrm{P}-27.21435==1680+24+120+16+0=1840$

$\mathrm{P}-28.21453==>1680+24+120+2415+0=4239$

P-29. $21534==>1680+24+180+16+0=1900$

P-30. $21543==>1680+24+180+180+0=2064$ 
$\mathrm{P}-31.23145==>1680+2520+120+180+0=4500$ P-32. $23154==>1680+2520+120+2415+0=6735$ P-33. $23415==1680+2520+120+10+0=4330$ P-34. $23451==>1680+2520+120+2415+0=6735$ P-35. $23514==1680+2520+180+10+0=4390$ P-36. $23541==>1680+2520+180+180+0=4560$ P-37. $24135==1680+2415+120+16+0=4231$ $\mathrm{P}-38.24153==>1680+2415+120+2415+0=6630$ $\mathrm{P}-39.24315==>1680+2415+2415+10+0=6520$ $\mathrm{P}-40.24351==>1680+2415+2415+2415+0=8925$ $\mathrm{P}-41.24513=\Rightarrow 1680+2415+180+10+0=4285$ $\mathrm{P}-42.24531=\Rightarrow 1680+2415+180+16+0=4291$ P-43. $25134==>1680+15+120+16+0=1831$ P-44. $25143==>1680+15+120+180+0=1995$ $\mathrm{P}-45.25314=\Rightarrow 1680+15+2415+10+0=4120$ P-46. $25341=\Rightarrow 1680+15+2415+180+0=4290$ P-47. $25413==>1680+15+120+10+0=1825$ P-48. $25431==>1680+15+120+16+0=1831$ P-49. $31245==>120+24+24+180+0=348$ >> Best So Far $=348$

P-50. $31254=\Rightarrow 120+24+24+2415+0=2583$ $\mathrm{P}-51.31425==>120+24+120+2424+0=2688$ P-52. $31452==>120+24+120+2415+0=2679$ P-53. $31524==>120+24+180+2424+0=2748$ P-54. $31542=\Rightarrow 120+24+180+180+0=504$ $\mathrm{P}-55.32145==>120+24+120+180+0=444$ P-56. $32154==>120+24+120+2415+0=2679$ P-57. $32415==120+24+120+10+0=274$ $>$ Best So Far $=274$

P-58. $32451==>120+24+120+2415+0=2679$ P-59. $32514=>120+24+180+10+0=334$ P-60. $32541==>120+24+180+180+0=504$ P-61. $34125=\Rightarrow 120+2415+120+2424+0=5079$ P-62. $34152==>120+2415+120+2415+0=5070$ P-63. $34215=\Rightarrow 120+2415+24+10+0=2569$ P-64. $34251==>120+2415+24+2415+0=4974$ P-65. $34512=>120+2415+180+10+0=2725$ P-66. $34521==>120+2415+180+2424+0=5139$ P-67. $35124==>120+15+120+2424+0=2679$ P-68. $35142==>120+15+120+180+0=435$ P-69. $35214==>120+15+24+10+0=169$ >> Best So Far $=169$

P-70. $35241=>120+15+24+180+0=339$ P-71. $35412=>120+15+120+10+0=265$ P-72. $35421==>120+15+120+2424+0=2679$ P-73. $41235==>120+24+24+16+0=184$ P-74. $41253=\Rightarrow 120+24+24+2415+0=2583$ P-75. $41325=\Rightarrow 120+24+2415+2424+0=4983$ P-76. $41352=>120+24+2415+2415+0=4974$ $\mathrm{P}-77.41523=\Rightarrow 120+24+180+2424+0=2748$ P-78. $41532=>120+24+180+16+0=340$ P-79. $42135=\Rightarrow 120+24+120+16+0=280$ $\mathrm{P}-80.42153==>120+24+120+2415+0=2679$ P-81. $42315==>120+24+2415+10+0=2569$ $\mathrm{P}-82.42351==>120+24+2415+2415+0=4974$ $\mathrm{P}-83.42513=>120+24+180+10+0=334$ P-84. $42531=\Rightarrow 120+24+180+16+0=340$ $\mathrm{P}-85.43125==>120+2520+120+2424+0=5184$ P-86. $43152==>120+2520+120+2415+0=5175$ $\mathrm{P}-87.43215==>120+2520+24+10+0=2674$ P-88. $43251==>120+2520+24+2415+0=5079$
P-89. $43512==>120+2520+180+10+0=2830$ P-90. $43521==>120+2520+180+2424+0=5244$ P-91. $45123=\Rightarrow 120+15+120+2424+0=2679$ P-92. $45132=>120+15+120+16+0=271$ P-93. $45213==>120+15+24+10+0=169->$ Best So Far

P-94. $45231==120+15+24+16+0=175$

P-95. $45312==>120+15+2415+10+0=2560$ P-96. $45321==>120+15+2415+2424+0=4974$ P-97. $51234==>2520+24+24+16+0=2584$ P-98. $51243==>2520+24+24+180+0=2748$ P-99. $51324==>2520+24+2415+2424+0=7383$ $\mathrm{P}-100.51342==>2520+24+2415+180+0=5139$ a.

$\mathrm{P}-101.51423==>2520+24+120+2424+0=5088$ $\mathrm{P}-102.51432==>2520+24+120+16+0=2680$ $\mathrm{P}-103.52134==>2520+24+120+16+0=2680$ P-104. $52143==>2520+24+120+180+0=2844$ P-105. $52314=>2520+24+2415+10+0=4969$ $\mathrm{P}-106.52341==>2520+24+2415+180+0=5139$ $\mathrm{P}-107.52413==>2520+24+120+10+0=2674$ $\mathrm{P}-108.52431==>2520+24+120+16+0=2680$ $\mathrm{P}-109.53124==>2520+2520+120+2424+0=7584$ $\mathrm{P}-110.53142==>2520+2520+120+180+0=5340$ $\mathrm{P}-111.53214==>2520+2520+24+10+0=5074$ $\mathrm{P}-112.53241==>2520+2520+24+180+0=5244$ $\mathrm{P}-113.53412==>2520+2520+120+10+0=5170$ $\mathrm{P}-114.53421==>2520+2520+120+2424+0=7584$ $\mathrm{P}-115.54123==>2520+2415+120+2424+0=7479$ $\mathrm{P}-116.54132==2520+2415+120+16+0=5071$ $\mathrm{P}-117.54213==2520+2415+24+10+0=4969$ $\mathrm{P}-118.54231==2520+2415+24+16+0=4975$ $\mathrm{P}-119.54312==>2520+2415+2415+10+0=7360$ P-120. $54321==>2520+2415+2415+2424+0=9774$ >> > Best So Far $=169$,

at the 69th assignment, Received

TABLE III. MATRIX COST

\begin{tabular}{|c|c|c|c|c|c|}
\hline & $\mathrm{X} 1$ & $\mathrm{X} 2$ & $\mathrm{X} 3$ & $\mathrm{X} 4$ & $\mathrm{X} 5$ \\
\hline $\mathrm{Y} 1$ & 120 & 2520 & 1680 & 1616 & 120 \\
\hline $\mathrm{Y} 2$ & 2520 & 1524 & 24 & 24 & 15 \\
\hline $\mathrm{Y} 3$ & 2415 & 180 & 24 & 120 & 120 \\
\hline $\mathrm{Y} 4$ & 16 & 2415 & 2424 & 10 & 180 \\
\hline $\mathrm{Y} 5$ & 0 & 0 & 0 & 0 & 0 \\
\hline
\end{tabular}

And so on until the 5th Iteration (the process until the 5th iteration is in the attachment section). From the Iteration process to 5th iteration, the final results are obtained as follows:

- Best assignment = 35214

- Total Cost = 169 Information:

A value of $9999999=$ is the value given to an assignment that has the same value, so as not to take the same smallest value. From the above calculation, tabu search algorithm can be analyzed in the scheduling process. The matching process is a taboo list of several data inputs namely Lecturer Data, Subject Data and Room Data which are local solutions compared to neighbor solutions. This algorithm uses class and subject relations as variables and uses lecturers, subjects, time, and space as values that will be included in the existing variables. Every step taken by Tabu Search is taken based on the results 
of the cost calculation carried out in each iteration to select a neighbor solution which will be the next current best solution. Termination of the process occurs if the number of scheduled classes has met the requirements or interaction of the user requires the termination of the process.

\section{CONCLUSION}

- Lecture scheduling application using Tabu Search method is designed using Microsoft Visual Basic programming by entering several parameters namely Data Lecturer, Course, Room, and several variables from each parameter which are then processed so as to produce lecture scheduling. In Tabu Search, parameters of Course Data, Lecturer, and Room are local searches that are entered in the matching process (taboo list) first which then results in the schedule output of the course.

- Violations of the constraints on the Tabu Search Method method are violations of 8 and the time used to obtain a schedule with a $90 \%$ truth level is tabu search where the process is faster, and the best results from the iteration process (Global min).

\section{REFERENCES}

[1] I. Berlianty, and A. Miftahol, Teknik-Teknik Optimasi Heuristik,Yogyakarta: Graha Ilmu, 2010.

[2] M. Gendreau, and J.Y. Potvin, Handbook of Metaheuristics: Second Edition, New York: Springer Science+Business Media, 2010.

[3] F. Glover, and G.A. Kochenberger, Handbook of Metaheuristics. Dordrecht: Kluwer Academic Publisher, 2003.

[4] F. Glover, and M. Laguna, Tabu Search, Massachusetts: Kluwer Academic Publisher, 1997.

[5] A. Hertz, E. Taillard, and D.D. Werra, . A Tutorial on Tabu Search . EPFL, Departement de Mathematiques, MA-Ecublens, CH-1015: Laussanne, 2002.

[6] S. Kusumadewi, Artificial Intelligence (Teknik dan Aplikasinya) Yogyakarta : Graha Ilmu, 2003.

[7] S. Kusumadewi, and H. Purnomo, Penyelesaian Masalah Optimasi dengan Teknik-teknik Heuristik, Yogyakarta : Graha Ilmu, 2005.

[8] A.P. Nugroho, Desain dan Implementasi Business Intelligence Untuk Mendukung Pembuatan Keputusan, Tesis Magister, Institut Teknologi Bandung, 2003.

[9] R.T. Grauer, and M. Barber. Microsoft Office Access 2013 revised comprehensive.UpperSaddle River, NJ,: Prentice Hall, 2006. 